\title{
Penerapan teknologi biopori vertikal dengan memanfaatkan larva Black Soldier Fly sebagai pengurai
}

\author{
Andi Dahliaty ${ }^{*}$, Halida Sophia, Yuana Nurulita, \& Sri Helianty \\ Universitas Riau \\ * andi.dahliaty@lecturer.unri.ac.id
}

\begin{abstract}
Abstrak. Lubang resapan biopori adalah lubang yang berdiameter $10 \mathrm{~cm}-30 \mathrm{~cm}$ dengan kedalaman $30 \mathrm{~cm}-100 \mathrm{~cm}$ yang ditambahkan sampah organik dan akan memicu biota tanah membentuk lubang biopori sehingga dapat menjebak air yang mengalir di sekitarnya. Larva Black Soldier Fly mampu mempercepat pengomposan dan pembentukan poripori didalam lubang resapan biopori. Perumahan Putri Indah Kulim RT 02 RW 12 Kelurahan Mentangor jarang ditemui lahan terbuka dan lahan kosong telah dilakukan semenisasi dan pelebaran rumah yang menyebabkan berkurangnya permukaan resapan air tanah sehingga saat musim penghujan mudah terjadi genangan dan saat musim kemarau mengurangi cadangan air tanah. Kegiatan ini bertujuan untuk memberikan pengetahuan dan wawasan kepada masyarakat tentang lubang resapan biopori dengan memanfaatkan larva Black Soldier Fly dan mengajak masyarakat untuk menerapkan teknologi ini. Kegiatan pengabdian ini diawali dengan sosialisasi tentang lubang resapan biopori kemudian dilakukan pengenalan alat dan bahan serta praktek langsung dilapangan. Hasil kegiatan ini memberikan pengaruh positif terhadap masyarakat serta banyak warga masyarakat yang ingin menerapkan teknologi lubang resapan biopori dengan menggunakan larva Black Soldier Fly. Ini merupakan langkah awal dalam rangka menciptakan lingkungan yang bersih dan sehat khususnya di Perumahan Putri Indah Kulim RT 02 RW 12 Kelurahan Mentangor.
\end{abstract}

Kata kunci: biopori, resapan, organik, penguraian, larva

\begin{abstract}
The biopore infiltration hole is a hole with a diameter of $10 \mathrm{~cm}-30 \mathrm{~cm}$ with a depth of $30 \mathrm{~cm}-100 \mathrm{~cm}$ which is added with organic waste and will help soil biota form a biopore hole so that it can trap the air flowing around it. Black Soldier Fly larvae are able to accelerate composting and ordering of pores in the biopore infiltration holes. Perumahan Putri Indah Kulim RT 02 RW 12 Kelurahan Mentangor rarely finds open land semisization and house widening which causes a reduction in the surface of ground air infiltration so that during the rainy season puddles easily occur and during the dry season it reduces groundwater reserves. This activity aims to provide knowledge and insight into the community about biopore infiltration holes by utilizing Black Soldier Fly larvae and inviting the public to apply this technology. This service activity begins with the socialization of the biopore infiltration holes, then introduces the tools and materials as well as direct practice in the field. The results of this activity had a positive influence on the community and many community members who wanted to apply the biopore infiltration hole technology using Black Soldier Fly larvae. This is the first step in creating a clean and healthy environment, especially in Putri Indah Kulim Housing RT 02 RW 12 Mentangor Village.
\end{abstract}

Keywords: biopore, infiltration, organic, decompose, larvae

To cite this article: Dahliaty, A., H. Sophia., Y. Nurulita., \& S. Helianty. 2020. Penerapan teknologi biopori vertikal dengan memanfaatkan larva Black Soldier Fly sebagai pengurai. Unri Conference Series: Community Engagement 2: 207-214. https://doi.org/10.31258/unricsce.2.207-214

(C) 2020 Authors

Peer-review under responsibility of the organizing committee of Seminar Nasional Pemberdayaan Masyarakat 2020 


\section{PENDAHULUAN}

Pemanfaatan sumber daya alam yang berupa tanah dan air harus dilakukan dengan sebaik-baiknya. Pemanfaatan sumber daya alam khusunya tanah dan air, jika tidak sesuai dengan kaidah-kaidah konservasi dan pemanfaatan yang berlebihan dapat menyebabkan bencana seperti banjir (Hilwatullisan, 2010). Pengambilan air tanah yang tidak diimbangi dengan pemasukkan air hujan kembali kedalam tanah akan berakibat pada berkurangnya ketersediaan air tanah (Yohana, Griandini and Muzambeq, 2017). Seperti yang dinyatakan oleh (Samadikun, 2019) bahwa semakin banyaknya lahan terbangun dan kurangnya Ruang Terbuka Hijau (RTH) maka akan mengakibatkan berkurangnya kawasan resapan air bagi masyarakat. Pengurangan daerah resapan ini diakibatkan oleh banyaknya lahan produktif yang beralih fungsi menjadi perumahan, ruko dan lain-lain. Dengan berkurangnya peresapan maka air hujan langsung mengalir kesungai yang selanjutnya menuju ke laut (Yohana, Griandini and Muzambeq, 2017). Sehingga berkurangnya zona peresapan air hujan menjadi salah satu penyebab menurunnya sumberdaya air tanah. Hal ini bila tidak dikelola dengan baik, akan menyebabkan berkurangnya cadangan air tanah. Padahal, air tanah masih menjadi sumber utama dalam pemenuhan air bersih oleh masyarakat (Samadikun, 2019). Selain itu, kurangnya daerah resapan air di pekarangan rumah akan memperbesar potensi terjadinya banjir di wilayah perkotaan (Elsie et al., 2017). Upaya yang dilakukan untuk mengendalikan kondisi ini antara lain dengan pembuatan lubang resapan biopori. Lubang resapan biopori adalah lubang yang berdiameter $10 \mathrm{~cm}-30 \mathrm{~cm}$ dan kedalaman $30 \mathrm{~cm}-100 \mathrm{~cm}$ yang ditambahkan sampah organik untuk menjebak air yang mengalir di sekitarnya sehingga dapat menjadi sumber cadangan air bagi air bawah tanah dan tumbuhan di sekitarnya serta dapat juga membantu penguraian sampah organik menjadi kompos yang bisa dipakai untuk pupuk tanaman (Yohana, Griandini and Muzambeq, 2017).

Studi yang sudah dilakukan menunjukkan bahwa jika lubang biopori diisi dengan sampah organik, maka permukaan resapan tidak akan tersumbat karena sampah organik akan membusuk dan meresap air (Widyastuti, 2013). Sampah organik berpotensi menjadi pupuk kompos yang bermanfaat bagi rumah tangga serta memiliki nilai jual (Permanasari, 2018). Bahan organik yang digunakan dapat diperoleh dari berbagai sumber antara lain sampah dapur rumah tangga, potongan atau pangkasan tanaman, sisa produksi pertanian yang tidak dimanfaatkan dan sebagainya (Wiedarti, Lubis and Komala, 2015).

Larva BSF (Black Soldier Fly) dapat dimanfaatkan untuk mengkonversi materi organik sehingga memiliki potensi ekonomi. Larva BSF mampu mendegradasi sampah organik, baik sampah yang berasal dari hewan maupun tumbuhan. Selain itu, keberadaan larva BSF dinilai cukup aman bagi kesehatan manusia (Ambarningrum, Srimurni and Basuki, 2019). Temuan lain, BSF dapat mengurangi bau tak sedap karena proses pencernaan berlangsung lebih cepat sehingga proses dekomposisi juga berjalan lebih cepat. Selain itu, BSF dapat mengendalikan populasi lalat rumah (Musca domestica) sekitar 94-100\% di peternakan unggas dan kotoran babi dengan mencegah proses bertelur lalat tersebut. Larva BSF juga mengandung antibiotik alami yang dapat mencegah penyebaran penyakit. Peneliti lain juga melaporkan bahwa Larva BSF menekan Escherichia coli dan Salmonella enteric serovar enteritidis (Sanjaya et al., 2019). .

Larva BSF ini tergolong "kebal" dan dapat hidup di lingkungan yang cukup ekstrim, seperti di media/sampah yang banyak mengandung garam, alkohol, asam dan amonia (Suciati et al., 2017). Pakan larva dengan ampas tahu pada pemberian pakan $50 \mathrm{mg}$ / larva / hari dan limbah sayuran pada tingkat 12,5 mg / larva / hari menunjukkan efisiensi konversi tertinggi yaitu 48,10 \% dan 49,54 \% (Kinasih et al., 2018). Menurut (Muhayyat, Yuliansyah and Prasetya, 2016), larva Hermetia Illucens memiliki kandungan protein yang mencapai $45-50 \%$ dan lemak yang mencapai $24-30 \%$. Karena kandungan protein tinggi inilah beberapa produsen pakan telah menjadikannya sebagai pengganti pakan ikan (Rambet et al., 2016). Disamping itu cairan hasil aktivitas larva dapat digunakan sebagai pupuk cair dan sisa limbah organik dapat digunakan sebagai kompos (Suciati et al., 2017). Dari karakter larva dan lalat BSF tersebut sehingga dianggap cocok jika digunakan sebagai pemercepat proses penguraian sampah organik yang akan ditambahkan kedalam lubang resapan biopori. 


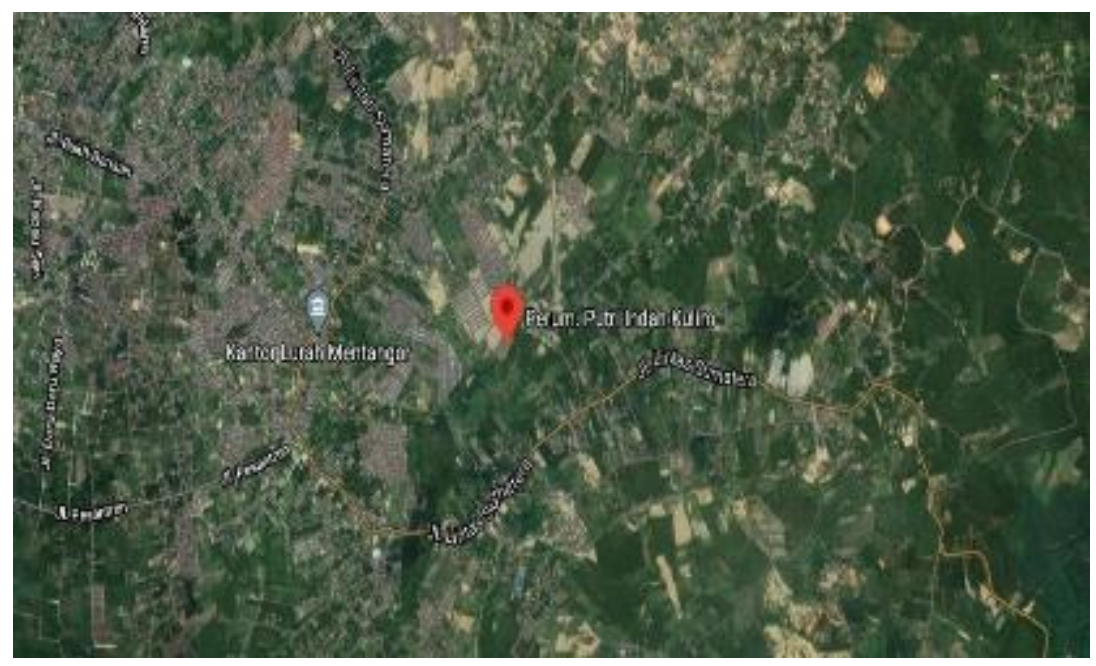

Gambar 1. Lokasi Kegiatan Pengabdian di Perumahan Putri Indah Kulim, Kecamatan Tenayan Raya, Kelurahan Mentangor

Lokasi kegiatan pengabdian ini dilakukan di perumahan putri indah kulim, kecamatan tenayan raya, kelurahan mentangor. Pada perumahan ini memiliki luas lahan yang sempit dan berkurangnya lahan kosong sehingga luas lahan terbuka hijau berkurang karena umumnya telah dilakukan semenisasi baik untuk perluasan bangunan atau tujuan lainnya. Hal ini dikhawatirkan dapat menyebabkan daerah resapan air menjadi berkurang yang berakibat munculnya genangan air ketika terjadi musim hujan. Selain itu, untuk memenuhi kebutuhan air bersih, warga di perumahan ini menggunakan sumur bor yang dapat mengurangi cadangan air bawah tanah dan ketika musim kemarau dikhawatirkan akan mengalami kekeringan.

Untuk mengatasi permasalahan tersebut, maka perlu diperkenalkan teknologi lubang resapan biopori ini sebagai model yang tepat guna yaitu teknologi peresapan air yang ramah lingkungan. Adanya teknologi ini diharapkan dapat memberikan pengetahuan dan wawasan kepada masyakat tentang lubang resapan biopori dengan bantuan larva bsf sekaligus dapat mendorong masyarakat untuk menerapkan teknologi ini dirumahnya masing-masing.

\section{METODE PENERAPAN}

Waktu pelaksanaan kegiatan pengabdian ini dilakukan selama 2 bulan, yaitu bulan Juli dan Agustus 2020. Pelaksanaan Kegiatan Pengabdian Masyarakat ini dengan skema Pengabdian Masyarakat (PPM) melibatkan berbagai pihak terkait diantaranya tim pelaksana terdiri dari 4 orang, mahasiswa kukerta terintegrasi abdimas tahun 2020 sebanyak 10 orang, pihak Kelurahan Mentangor, dan warga Perumahan Putri Indah Kulim RT 02 RW 12 sebagai mitra pada kegiatan pengabdian ini.

Kegiatan pengabdian ini dilakukan di Kecamatan Tenayan Raya Kelurahan Mentangor RW 12 RT 02, tepatnya di Perumahan Putri Indah Kulim. Dengan kegiatan pengabdian ini diharapkan dapat membantu mencegah permasalahan banjir dan kelangkaan air tanah, karena masyarakat di Perumahan Putri Indah Kulim secara umum menggunakan air tanah sebagai sumber air bersih.

Metode pelaksanaan kegiatan berupa penyampaian materi dan praktek di lapangan. Tahapan awal pelaksanaan meliputi persiapan kegiatan yaitu a) koordinasi dengan pihak-pihak yang terkait dengan kegiatan pengabdian ini, diantaranya adalah Lurah, Babinsa, Ketua Kamtibmas (Keamanan dan Ketertiban Masyarakat), RW, dan RT setempat; b) sosialisasi rencana kegiatan kepada seluruh perangkat kelurahan; c) sosialisasi dan pendampingan kepada warga menggunakan media presentasi berupa powerpoint yang diawali dengan ceramah dan diskusi (tanya jawab), lalu diakhiri dengan praktek pembuatan contoh lubang resapan biopori dilapangan. Gambar 1 menunjukkan tim pengabdian telah melakukan koordinasi dengan berbagai pihak (Lurah, Babinsa, Ketua Kamtibmas, RW, dan RT setempat.

Kegiatan sosialisasi ini dilakukan oleh mahasiswa kukerta terintegrasi abdimas di dampingi oleh Dosen Pembimbing Lapangan (DPL) yang juga merupakan ketua dari tim kegiatan pengabdian ini. Sosialisasi ini dibuka oleh pembawa acara lalu dilanjutkan dengan pemaparan materi tentang lubang resapan biopori dan pemanfaatan larva Black Soldier Fly sebagai agen pengomposan pada lubang resapan biopori. Penyampaian materi ini bertujuan untuk memberikan pemahaman tentang manfaat lubang resapan biopori dan pemanfaatan 
larva Black Soldier Fly sebagai agen pengomposan pada lubang resapan biopori. Suasana kegiatan sosialisasi ini dapat dilihat pada Gambar 2.
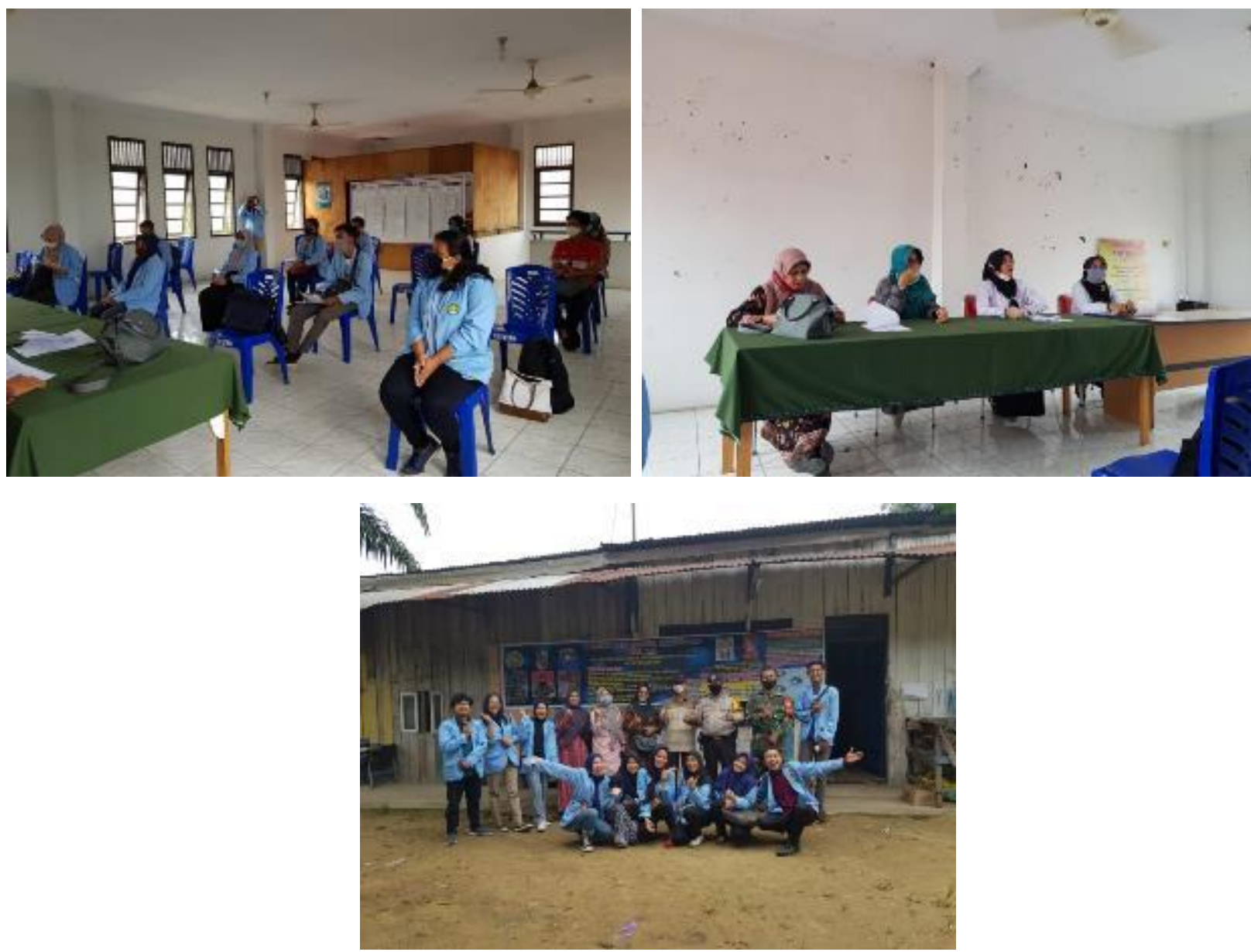

Gambar 2. Tim Pengabdian Melakukan Koordinasi dengan berbagai pihak dan menyampaikan rencana kegiatan pengabdian
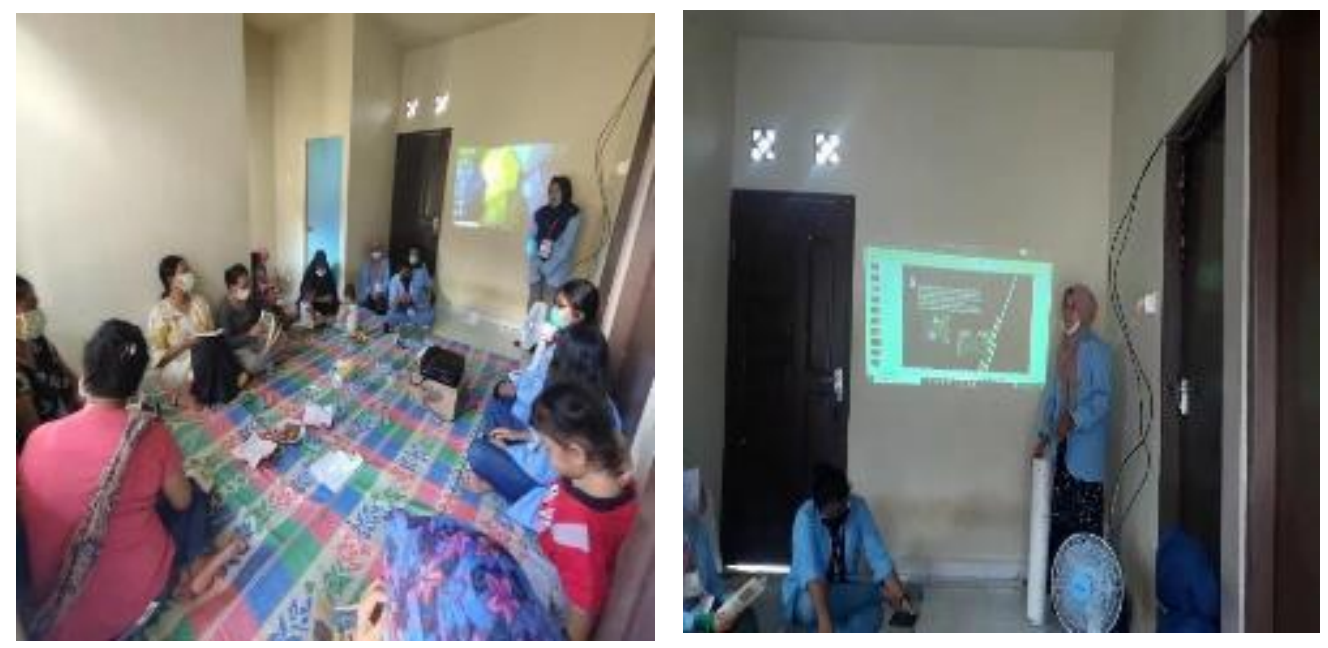

Gambar 3. Suasana Kegiatan Sosialisasi

Setelah penyampaian materi, tim pengabdian masyarakat melakukan praktek pembuatan lubang resapan biopori. Tujuannya adalah agar warga masyarakat dapat melihat secara langsung tahapan-tahapan, alat dan 
bahan yang diperlukan, serta cara pembuatan lubang resapan biopori. Sehingga pada akhirnya, warga memiliki peningkatan keterampilan dan pengetahuan untuk menerapkan teknologi lubang resapan biopori ini di rumahnya masing-masing agar manfaat teknologi ini dapat dirasakan oleh lingkungan tempat tinggal khususnya di Perumahan Putri Indah Kulim.

Tahap pertama yang dilakukan sebelum membuat lubang resapan biopori adalah menentukan posisi yang tepat untuk lubang tersebut, posisi yang dipilih adalah daerah yang biasa tergenang air dan berada disudut suatu bangunan agar tidak mengganggu aktivitas. Setelah menentukan posisi lubang kemudian dibuat lubang vertikal dengan diameter $10 \mathrm{~cm}$ dan kedalaman $100 \mathrm{~cm}$, selama proses pengeboran dilakukan penambahan air sesuai kebutuhan untuk melunakkan tanah. Jarak antara lubang lebih kurang $100 \mathrm{~cm}$. kedalaman lubang ini tidak boleh mencapai muka air tanah.

Untuk daerah dengan tanah yang gembur atau berpasir digunakan pipa PVC yang sekelilingnya telah dilubangi. Kemudian kedalam lubang ditambahkan sampah-sampah organik, setelah itu ditambahkan juga larva Black Soldier Fly kedalam lubang. Untuk tutup dari lubang resapan biopori ini digunakan potongan keramik yang telah dipotong sesuai dengan ukuran lubang.

Ketercapaian kegiatan ini diukur dari proses dan perubahan tingkat pemahaman warga terhadap kegiatan pembuatan lubang resapan biopori dengan memanfaatkan larva Black Soldier Fly. Evaluasi proses dapat dilihat dari minat atau antusias dari warga peserta kegiatan pengabdian saat pemberian materi. Sedangkan evaluasi pengetahuan masyarakat tentang materi kegiatan pengabdian dilihat dari persentase menjawab benar pada soal kuis yang diberikan oleh tim Pengabdian.

\section{HASIL DAN KETERCAPAIAN}

Pada RW 12 RT 02 Kelurahan Mentangor Kecamatan Tenayan Raya tepatnya diperumahaan Putri Indah Mentangor, lahan terbuka sudah jarang ditemui. Menurut (Yohana, Griandini and Muzambeq, 2017) pemenuhan kebutuhan ruang kota, khususnya perumahan terus mengalami peningkatan dalam 20 tahun terakhir.

Hal ini sebagai akibat meningkatnya aktivitas sosial-ekonomi masyarakat. Sedangkan disisi lain, yaitu luasan ruang yang ada sangat terbatas, semakin langka dan mahal, sehingga mendorong pemanfaatan ruang yang bersifat memaksimalkan kondisi ruang yang ada. (Samadikun, 2019) menyatakan bahwa tidak adanya aturan khusus dari pengembang yang membatasi penghuni untuk melakukan pembangunan atau pengembangan rumah sehingga penghuni pada umumnya melakukan semenisasi dan pembangunan pada sisa lahan yang berupa ruang terbuka (open space). Hal ini merupakan penyebab dari kurangnya lahan terbuka yang dapat menyebabkan banjir dan kelangkaan air tanah.
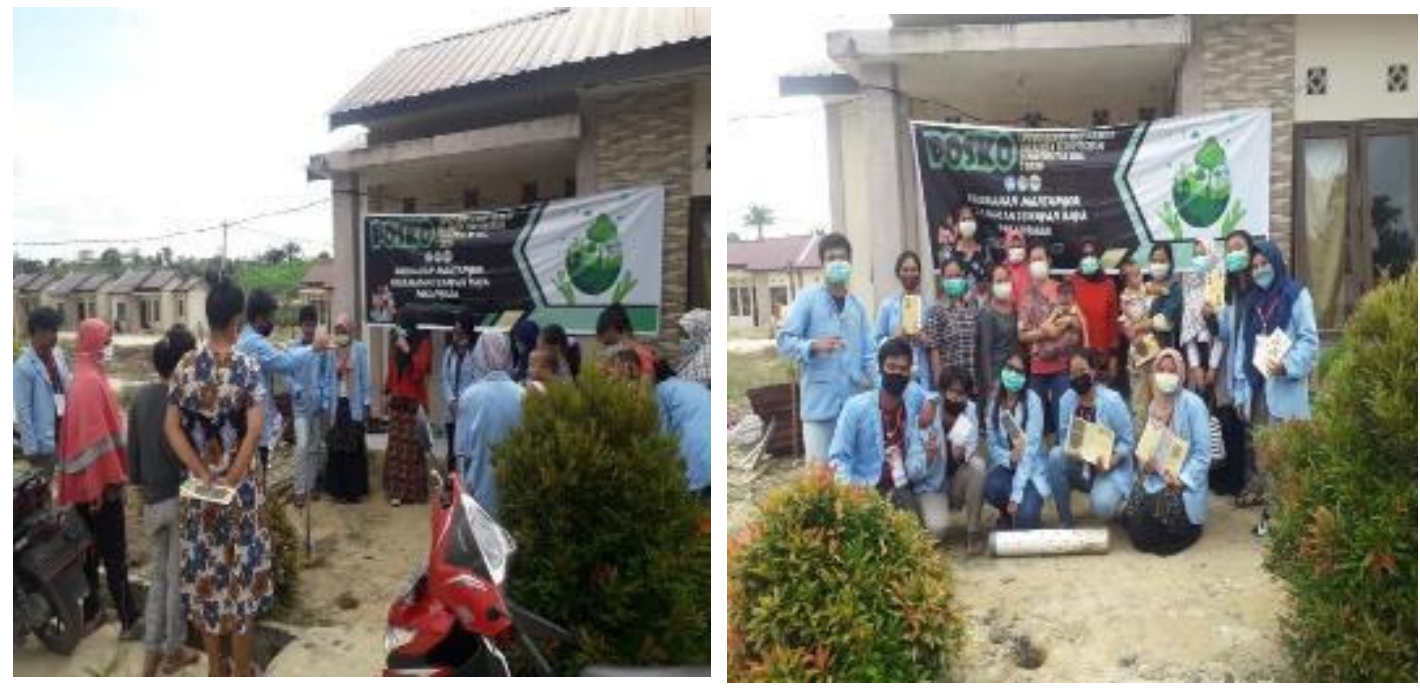

Gambar 4. Sosialisasi dan Praktek Pembuatan Lubang Resapan Biopori di Lapangan

Warga di Perumahan Putri Indah Mentangor hampir semuanya menggunakan air tanah untuk memenuhi kebutuhan sehari-hari kecuali untuk air minum dan memasak. Menurut (Yohana, Griandini and Muzambeq, 2017) dengan berkurangnya peresapan maka air hujan langsung mengalir kesungai yang selanjutnya menuju 
ke laut. Hal ini akan menyebabkan kelangkaan air tanah sehingga daerah resapan yang ada dimaksimalkan dengan membuat lubang resapan biopori di perumahan warga. Pembuatan lubang resapan biopori vertikal dapat memperluas permukaan serap tanah, sehingga air yang terserap lebih banyak (Widyastuti, 2013).
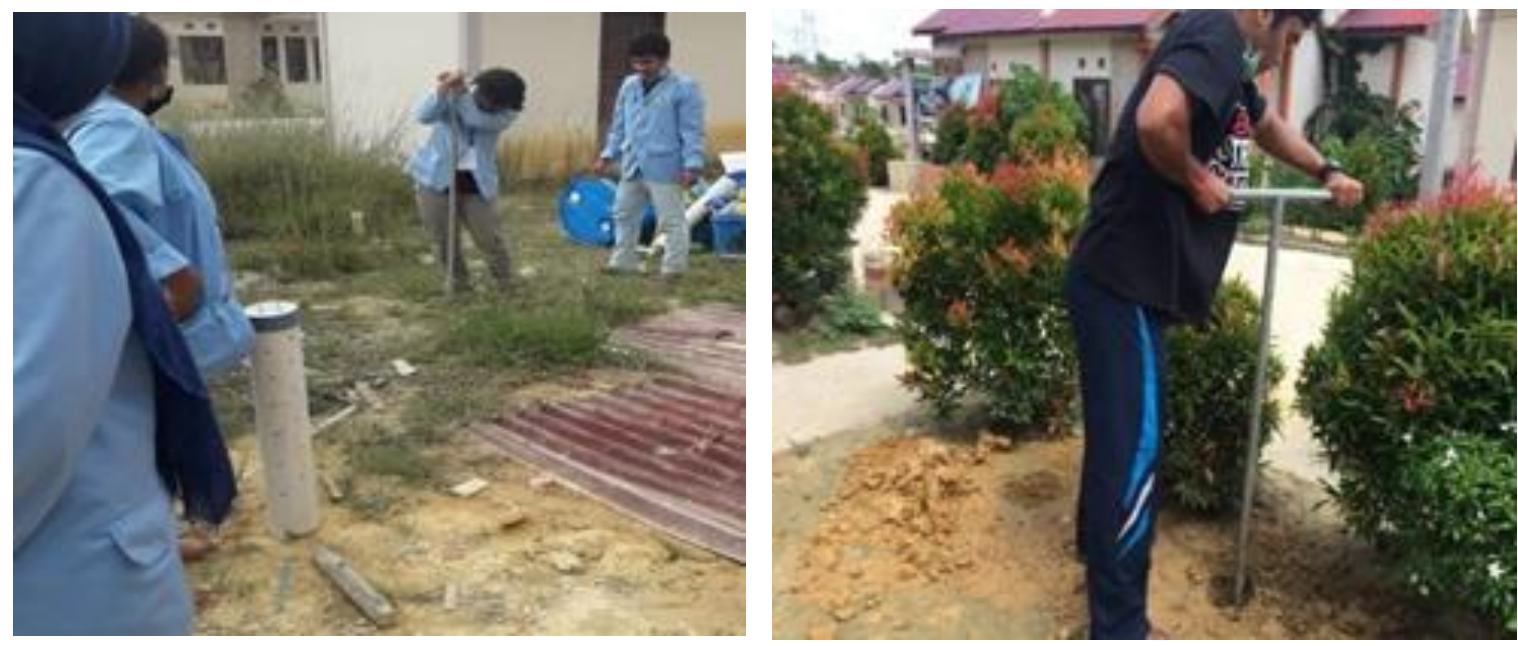

Gambar 5. Pembuatan Lubang Resapan Biopori di Rumah Warga

Penambahan sampah organik kedalam lubang resapan biopori dapat mengundang organisme kecil kedalam lubang resapan biopori, yang akan berkembang biak dan membuat pori-pori yang akan memperlancar aliran air ke dinding lubang resapan biopori. Selain itu proses pengomposan dapat menghasilkan kompos yang dapat digunakan untuk tanaman (Widyastuti, 2013). Kompos yang dihasilkan dari Lubang Resapan Biopori ini terbilang sedikit sehingga lebih cocok jika digunakan sebagai kompos untuk tanaman dengan metode tanam vertikultur dan menggunakan polybag seperti yang sudah diterapkan oleh tim pengabdian di Perumahan Putri Indah Kulim.
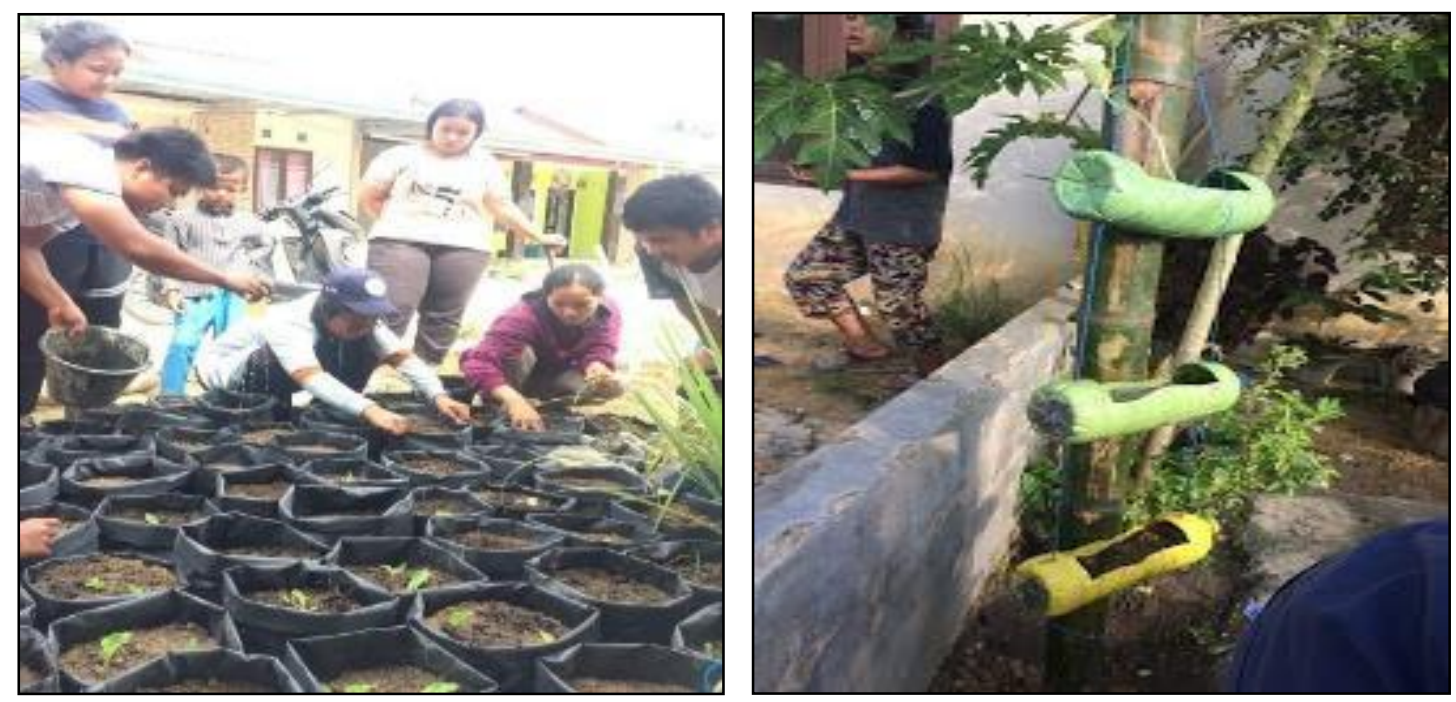

Gambar 6. Metode Tanam pada Polybag dan Vertikultur

Penambahan larva Black Soldier Fly mampu mempercepat proses pengomposan didalam lubang resapan biopori sehingga pembentukan pori-pori terjadi lebih cepat. Menurut (Kinasih et al., 2018), larva Black Soldier Fly mampu memakan sampah hingga $50 \mathrm{mg} / \mathrm{hari} /$ larva, sehingga cocok digunakan dalam lubang resapan biopori. 

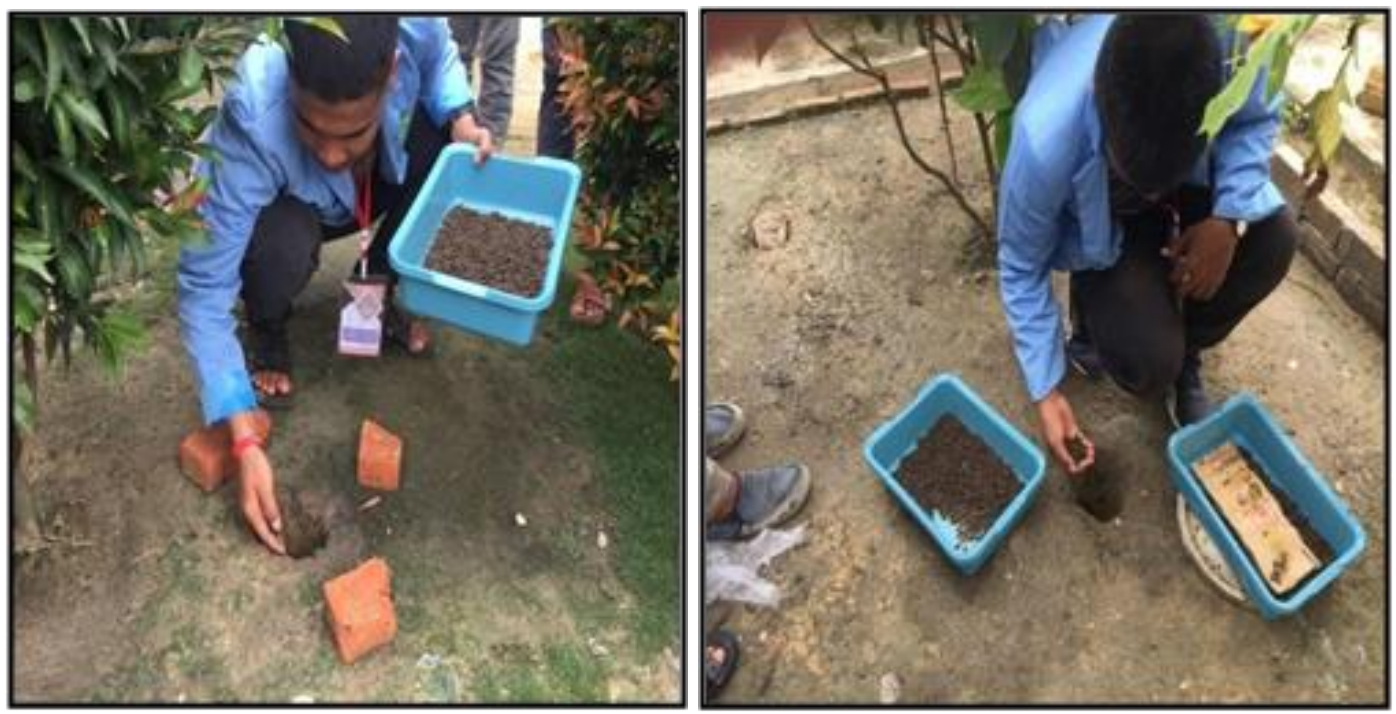

Gambar 7. Penambahan Larva Black Soldier Fly Kedalam Lubang Resapan Biopori

Pembuatan lubang resapan biopori ini diharapkan mampu mengatasi permasalahan seperti genangan air musim penghujan dan kelangkaan air tanah bahkan kekeringan saat musim kemarau. Kegiatan ini diikuti oleh 10 orang mahasiswa kukerta integrasi, perwakilan RT 02, 9 orang warga perumahan putri indah kulim dan didampingi oleh Dosen Pembimbing Lapangan Ibu Andi Dahliaty. Acara sosialisasi dilakukan di posko Tim Pengabdian UNRI. Peserta sosialisasi terlihat antusias mendengarkan pemaparan materi oleh mahasiswa dan peserta juga terlihat aktif dan memberikan pertanyaan saat dilakukan praktek pembuatan lubang resapan biopori.

\section{Hasil Evaluasi}

Hasil evaluasi terlihat dari peningkatan pengetahuan masyarakat tentang materi yang dipaparkan. Materi yang disosialisasikan meliputi materi tentang vertikultur, lubang resapan biopori (LRB) dan materi tentang aquaponik. Indikator keberhasilan penyampaian yang ditetapkan oleh tim adalah jika peserta sosialisasi secara keseluruhan mampu menjawab kuesioner dengan benar $80 \%$ atau lebih dari jumlah pertanyaan yang diberikan.

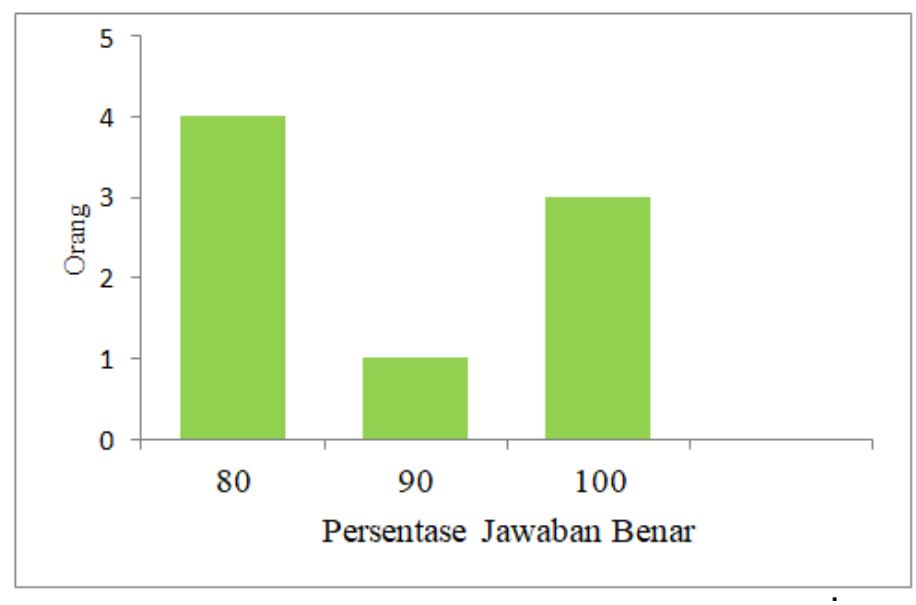

Gambar 8. Persentasi Jawaban Benar Hasil Kuesioner

Dari gambar terlihat bahwa dari 8 orang peserta sosialisasi sebanyak 4 orang berhasil menjawab kuesioner hingga persentase jawaban benar $80 \%$, satu orang menjawab benar $90 \%$ dan 3 orang menjawab $100 \%$ benar. Dari data tersebut rata-rata persentase jawaban benar adalah $88,75 \%$ sehingga kegiatan presentasi ini telah berhasil dilakukan karena telah mencapai indikator keberhasilan yang ditetapkan oleh tim pengabdian yaitu $80 \%$. 


\section{KESIMPULAN}

Dari Kegiatan Pengabdian ini dapat disimpulkan bahwa:

1. Pelaksanaan sosialisasi dan pemberian pelatihan kepada masyarakat dapat meningkatkan pengetahuan dan minat masyarakat untuk mengaplikasikan lubang resapan biopori di rumah masing-masing.

2. Pelaksanaan sosialisasi telah dilaksanakan dan mampu mencapai indikator keberhasilan. Hal ini terlihat dari rata-rata persentase jawaban benar masyarakat yaitu $88,75 \%$.

3. Diharapkan kepada tim pengabdian selanjutnya untuk melakukan pengkajian tentang lokasi lubang resapan biopori dengan pertimbangan keamanan dan efisiensi lubang resapan biopori.

4. Terdapat kendala yang dialami kegiatan sosialisasi berlangsung disebabkan peserta pelatihan merupakan ibu - ibu usia muda yang masih mempunyai balita. Jadi, tidak konsentrasi dalam mengikuti kegiatan sosialisasi di lokasi kegiatan.

\section{UCAPAN TERIMA KASIH}

Penulis mengucapkan terima kasih kepada Lembaga Penelitian dan Pengabdian kepada Masyarakat Universitas Riau yang telah menyandang dana pengabdian melalui DIPA Universitas Riau tahun 2020 dengan Nomor Kontrak 858/UN.19.5.1.3/PT.01.03/2020.

\section{DAFTAR PUSTAKA}

Ambarningrum, T.B., Srimurni, E. and Basuki, E., 2019. Teknologi Biokonversi Sampah Organik Rumah Tangga Menggunakan Larva Lalat Tentara Hitam (Black Soldier Fly/BSF), Hermetia Illucens. In: Prosiding Seminar dan Call for Papers 'Pengembangan Sumber Daya Perdesaan dan Kearifan Lokal Berkelanjutan IX'14-15 November 2019 Purwokerto. pp.235-243.

Elsie, Harahap, I., Herlina, N., Badrun, Y. and Gesriantuti, N., 2017. Pembuatan Lubang Resapan Biopori Sebagai Alternatif Penanggulangan Banjir di Kelurahan Maharatu Kecamatan Marpoyan Damai Pekanbaru. Jurnal Untuk Mu negeRI, 1(2).

Hilwatullisan, 2010. Lubang resapan biopori (lrb) pengertian dan cara membuatnya di lingkungan kita biopore hole definition and how to make it in down our way.

Kinasih, I., Putra, R.E., Permana, A.D., Gusmara, F.F. and Nurhadi, M.Y., 2018. Growth Performance of Black Soldier Fly Larvae (Hermetia illucens) Fed on Some Plant Based Organic Wastes. 25(2), 79-84.

Muhayyat, M.S., Yuliansyah, A.T. and Prasetya, A., 2016. Pengaruh Jenis Limbah dan Rasio Umpan pada Biokonversi Limbah Domestik Menggunakan Larva Black Soldier Fly (Hermetia illucens). 10(1),23-29.

Rambet, V., Umboh, J.F., Tulung, Y.L.R. and Kowel, Y.H.S., 2016. Kecernaan Protein dan Energi Ransum Broiler yang Menggunakan Tepung Maggot (Hermetia Illucens) Sebagai Pengganti Tepung Ikan. Jurnal Zootek, 36(1), 13-22.

Samadikun, B.P., 2019. Jurnal Presipitasi Penerapan Biopori untuk Meningkatkan Peresapan. Jurnal Presipitasi, 16(3), 126-132.

Sanjaya, Y., Suhara, Nurjhani, M. and Halimah, M., 2019. The role of black soldier fly (BSF) hermetia illuncens as organic waste treatment The role of black soldier fly (BSF) hermetia illuncens as organic waste treatment. In: Journal of Physics, 1-4.

Suciati, R., Faruq, H., Biologi, J.P. and Timur, J., 2017. Efektifitas Media Pertumbuhan Maggots Hermetia illucens (Lalat Tentara Hitam) Sebagai Solusi Pemanfaatan Sampah Organik. BIOSFER, J.Bio \& Pend.Bio., 2(1), 8-13.

Widyastuti, S., 2013. Perbandingan Jenis Sampah Terhadap Lama Waktu Pengomposan Dalam Lubang Resapan Biopori Oleh : Sri Widyastuti *). Jurnal Teknik WAKTU, 11, 5-14.

Wiedarti, S., Lubis, A.Y. and Komala, O., 2015. Aktivitas Degradasi Sampah Organik dalam Biopori. Ekologia, 15(1), $1-5$.

Yohana, C., Griandini, D. and Muzambeq, S., 2017. Penerapan Pembuatan Teknik Lubang Biopori Resapan Sebagai Upaya Pengendali Banjir. Jurnal Pemberdayaan Masyarakat Madani, 1(2), 296-308. 